\section{Cape Canaveral}

The June meeting of the chapter was held on the 21 st at the Dunes Restaurant; 24 members and five guests were present. The guest speaker was Jack Reed, of Sandia Labs in Albuquerque, N. Mex., who was at the Kennedy Space Center during testing on Blast Propagation for the Space Shuttle. He presented a program on power available from wind energy. He has been doing research in this area in New Mexico.

The 19 July meeting of the chapter was held at The Dunes Restaurant; 15 members and one guest were present. The guest speaker was Howard Bennett, from the Civil Defense in Brevard County. Speaking about Civil Defense Activities in the State of Florida, he gave some insight as to how Civil Defense reacts to a real emergency, and what the public should do when a disaster strikes.

The chapter's August meeting was held on the 9th, with 18 members and four guests present. Phillip Krider, from the University of Arizona, was guest speaker that evening. Krider has been in the area for the summer lightning studies held at the Kennedy Space Center. He gave a very interesting talk (supplemented by slides and graphs) about his findings during the past several years.-Brenda K. Ellis, Secy.

\section{Central Arizona}

The 28 March meeting was called to order by Co-President Claire Jensen. The topic was a panel presentation on "Major Storms and Floods in Arizona." The participants were: Robert Durrenberger, Director of the Laboratory of Climatology; John Hubbard, State University of New York at Brockport; and Harris Williams, Department of Geography, Arizona State University. There were 17 members and guests in attendance.

The April meeting, which 25 members and guests attended, was held on the 18 th at Luke AFB. A film describing the mission of the Base was shown, and Lt. Col. Bush conducted a tour of the Weather Detachment facility.

The annual May banquet meeting was held on the 16th at the Stockyards Restaurant. There were 33 members and guests present. The chapter awarded certificates of merit to R. W. Durrenberger, John Hubbard, Ray Lougeay, and Sandra Brazel. Lougeay, the featured speaker, presented an illustrated talk about the climate of Alaska and its similarities to the climate of Arizona. Also, officers for 1979-80 were elected.-Harold Bulk, Secy.

\footnotetext{
${ }^{1}$ Meeting reports received at Headquarters before 15 September 1979 are included. Copy from chapter representatives should be typed double-spaced and submitted in duplicate; photos accompanying reports should be black and white.Nerws Ed.
}

\section{Central New York}

The chapter held two meetings during April. The first took place on the SUNY (State University of New York) Oswego campus on the 4 th and featured Lee Davis, a meteorologist for Niagara Mohawk Power Co., as the main speaker. Davis discussed career opportunities in air pollution meteorology. His audience consisted, for the most part, of students at the college, a majority of whom are meteorology majors. This presentation included applications of meteorology to real problems in the air pollution field. He also noted that job opportunities in air pollution are increasing at a greater rate than in the profession as a whole. A lengthy questionand-answer session followed.

On 27 April, the final meeting for the school year was held on the campus of the SUNY College of Environmental Forestry in Syracuse, N.Y. About 20 members, and additional guests, were present. The speaker for the evening was Horace Meredith, a meteorologist for WIXT-TV in Syracuse; Meredith has been broadcasting the weather there for a number of years. His topic was "Long Range Forecasting and Lunar Influences." The moon presents forces of attraction on the earth's atmosphere in the same way the oceans experience this gravitational force, Meredith said, which may cause outbreaks of more dense polar air. According to his presentation, the existence of cycles is supported by many years of data. Both temperature and precipitation were forecast using this method. Handouts were distributed and questions followed. Meredith also added that computer predictions have come a long way, and their future seems bright. Refreshments and a short business meeting followed.

The business meeting centered on the election of new officers; elections will be held in the fall, at the first full meeting. In the meantime, the current officers will select candidates for the chapter positions. The chapter also tentatively decided to arrange a field trip to the Albany NWS Office and the Whiteface Mt. observatory, with details to be worked out over the summer. The next full meeting is scheduled for the latter part of September, after the new school year gets underway. Possible speaker topics include instrumented wind towers and shock waves resulting from lightning.-Richard S. Penc, Secy.

\section{Denver}

The first meeting of the new year was held 22 January at NCAR, Boulder, Colo. The guest speaker for the evening was Joseph Golden-a former chapter president (1977-78)of the NOAA Environmental Research Laboratory in Boulder. Golden discussed the similarities and differences between waterspouts and tornadoes. He also displayed, side by side, a series of slides of the two different phenomena; many of the slides were from his personal collection. The audience then was shown several film clips, including one of a tornado with a rare, anticyclonic circulation. Another showed a huge waterspout off the coast of North Carolina. After showing 
the films, Golden was questioned enthusiastically by the audience of approximately 40 members and guests.

The chapter's 21 February meeting was held at Physical Science Research Building No. 3, University of Colorado, Boulder. The evening's special guest speaker was Paul MacCready, President of Aerovironment Inc., in Pasadena, Calif. MacCready is designer and owner of the Gossamer Condor, the aircraft that claimed the long sought-after $£ 50000$ Kremer prize for man powered flight around a onemile course. The title of his talk was, "Son of Gossamer Condor-Man Powered Flight."

MacCready spoke to a standing room only audience of nearly 160 members and guests. The talk was preceded by the presentation of a documentary film outlining the events that culminated in the award-winning flight. Following the showing of the film, MacCready presented a slide show, during which he detailed the aircraft's design and construction. He concluded his talk by discussing his plans to win the $£ 100000$ Kremer prize for a man powered flight across the English Channel in his new aircraft, the Gossamer Albatross. He then answered numerous questions from an appreciative audience. ${ }^{2}-E d w a r d J$. Zipser, Pres.

\section{Derby City}

The chapter held its first meeting of $1978-79$ on 3 October. The speaker for the evening was Alan Fox of NWS Louisville. Fox previously had worked part-time with Carl Larson of the California Institute of Earth, Planetary, and Life Sciences on color composites of satellite images; they used three different colors to determine trends in clouds and temperature changes over various periods of time. The one used most frequently was a 30-day composite, consisting of three 10-day composites. For the first 10 days they used a red filter, the second 10 a green filter, and the third 10 a blue filter. The trends over a 30-day period could be seen by noting color and changes in color during the movie loop. Features visible in the months shown included shifting of maximum cloud cover, areas of cooling, and melting of snow. On a 90-day composite for the Winter of 1977, an area of cyclogenesis was detected, and this in itself was significant.

The 9 November meeting featured David Smith, from Fire Weather Focal Point at WSFO Louisville, as speaker. Louisville's fire forecast responsibility covers forests in Ohio, Indiana, and Kentucky and includes both national and state forests. During the fire weather season, spot forecasts are made for seven stations for maximum and minimum temperature and humidity, wind direction and speed, amount of clouds, type of weather, and the number of hours of precipitation. In determining fire danger, the forestry people use the Weather Service forecasts and also take into account the lightning risk, railroads in the area, and the number of expected campers. Using this information, they can determine the fuel moisture, the rate of speed of fire, the flame length, and the energy released.-Marilyn B. Scholz, Secy.

${ }^{2}$ Shortly after this meeting, the documentary film won an Academy Award. And a few months later, the MacCready team was successful in their first attempt to cross the Channel in the Gossamer Albatross.-News Ed.

\section{Houston}

Clayton Crooker, former climatologist for the State of Texas, presented an overview of 50 years as a meteorologist on 9 July at the University of St. Thomas. Approximately 30 people were present, along with the local television media. Following dinner, Crooker compared the mosaic of hemispheric satellite maps to an individual's response to the impact of other persons on his life. Even though some may affect him adversely, his attitude and response can result in beneficial effects on his capabilities and character. Cooker then traced flood forecasting development from early rule of thumb, through graphic analysis, to present computer capability.

The AMS was praised as the vehicle for bringing together the combined talents of government agencies, private industry, and the academic community to advance the level of professional service to all segments of society.

Illustrations highlighted Texas rainfall changes since 1971, and a micro-analysis of Harris County and surrounding counties from 1971 through the recent rain of 19 April 1979 was presented.

Chapter officers were elected for the coming year. They are: Leon F. Graves, President; William Hildreth, VicePresident; B. Dudley Tarlton, Treasurer; and James Schnebelt, Secretary.-James Schnebelt, Secy.

\section{Memphis}

The chapter met for a combination dinner-meeting on 22 May 1979 at Jim's Place East in Memphis. The short business meeting was conducted by Vice-Chairman Dave Brown, who then introduced the newly elected officers for the 1979-80 season. They are: Chairman, Norman Prosser; Vice-Chairman, Robert Howard; Secretary, Steve Letro; and Treasurer, George Quereau. All of the new officers are associated with the Memphis WSFO. Their business address is: NWS, Suite 403, 3171 Directors Row, Memphis, Tenn. 38131. The chapter is looking forward to a successful year under their leadership.-Emilio D. Vigil, Secy.

\section{Southeastern Michigan}

The 12 June meeting was called to order by Chairman Conrad Mason at Weber's Inn in Ann Arbor, following the chapter's annual banquet. About 40 persons attended. The election ballots to determine club officers for next year were counted by Nominations Committee members Fred Nurnberger and Ed Ryznar. Officers elected for next year are: Chairman, Dale E. Linvill, Michigan State University; Vice-Chairman, Anita Baker-Blocker, University of Michigan; Treasurer, Michael J. St. Peter, University of Michigan, student; and Secretary, Bruce Wadell, University of Michigan, student.

No motion was made to donate money to the current science fairs, as the opportunity for this is now past; Del Malzahn had represented the club at the science fairs at Ann Arbor and Detroit. Also, the committee handling the "Directory of Meteorologists to Provide Expert Testimony in Court Cases" reported preparing and mailing questionnaires to those concerned, but this effort has been dropped since the response was zero.

It was proposed that letters be sent to local colleges and universities advising them of the chapter's plan to award 
a $\$ 50$ prize for the most interesting paper on meteorology submitted by their students to the chapter at a meeting next year. The award should encourage those students who write papers for a similar AMS national competition, since students who did not win in the national competition could still win in the local competition. The rules for this would be similar to those used in the national competition. A motion was made and accepted to create a committee to publicize rules for a student's night miniseminar regarding meteorology presented to this chapter. Richard Foltman, Gus Korte, and Mike St. Peter volunteered to serve on the committee, to be headed by Richard Foltman.

The business meeting then was adjourned by the Chairman. It was followed by three speakers on the topic of "Ozone over Michigan: Past, Present and Future." Dale Linvill, Department of Agricultural Engineering, Michigan State University, spoke about the ozone's past; William Hooker, Department of Botany and Plant Pathology, Michigan State University, spoke about its present state; and Donald Stedman, Department of Atmospheric and Oceanic Science and Department of Chemistry, University of Michigan, spoke about its future.-Gus Korte, Secy.

\section{Twin Cities}

The 26 April meeting was called to order by the Chairman at the Soil Science Building, University of Minnesota. He presented the Nominating Committee's officer candidate list for the 1979-80 season. They are: Chairman, John Cawhorn; Vice-Chairman, Erling Weiberg; Secretary, Tom Fahey; and Treasurer, John Dooley, Jr. The Chairman then asked for additional nominations. Nominations were closed, the slate of candidates was approved by acclamation, and the Chairman declared the slate elected.

The Chairman reported that in recognition of the Twin Cities Chapter's recent sponsorship of meetings of the AMS Agriculture and Forest Meteorology and Biometeorology Committees, the National AMS had presented a gift of $\$ 100$ to the chapter. The Chairman complimented $\mathrm{Mr}$. Baker's program committee, Mr. Cross' general arrangements committee, and other Chapter members who participated in the successful program. The membership discussed ways to use the $\$ 100$ gift and the type of awards offered by the chapter to winners of meteorological exhibits at the annual Minnesota regional and state science fairs. Thereupon, a motion was made and accepted to place the $\$ 100$ in a special science fair account.

The Chairman then commented on the forthcoming annual banquet meeting scheduled for 17 May and announced the banquet would be held at the NCO Club on the Air Force Base.

After the business meeting, Noel Petit of the University of Minnesota discussed infrared heat balance at the earth's surface.-Erling M. Weiberg, Secy. announcements continued from page 1455

\section{AAAS Establishes Science, Engineering, and Diplomacy Fellowships Program}

The American Association for the Advancement of Science (AAAS), in cooperation with the State Department, invites post-doctoral to mid-career scientists or engineers to apply for two recently established Science, Engineering, and Diplomacy Fellowships.

Fellows will stay one year, beginning 1 September 1980 , working as staff officers in the State Department's Bureau of Oceans and International, Environmental, and Scientific Affairs, Potential assignments may include: assisting in developing and negotiating procedures with coastal nations for the conduct of marine scientific research, working on various international aspects of energy, assisting in monitoring and examining bilateral scientific and technical agreements between the United States and the People's Republic of China; or helping to carry out new State Department responsibilities for coordinating international science and technology activities of more than 29 federal agencies.

Prospective fellows must demonstrate exceptional competence in some area of science or engineering; be flexible; and have a strong interest or some experience in applying knowledge toward the solution of problems in the area of foreign affairs.

Salary is $\$ 23000$ annually. A secret security clearance must be obtained after selection.

Deadline for receipt of applications is 15 February 1980. For application materials write: Science, Engineering, and Diplomacy Fellows Program, American Association for the Advancement of Science, 1776 Massachusetts Ave., N.W., Washington, D.C. 20036.

continued on page 1467 